\title{
Tourism Development Towards Economic Sustainability of Local Communities in Parangtritis Tourism Area
}

\author{
Meitolo Hulu, M.Baiquni, Chafid Fandeli and Niken Wirasanti
}

Corresponding Author:

Meitolo Hulu

meitolohulu@yahoo.com

Received: 7 August 2018

Accepted: 15 September 2018

Published: 22 October 2018

Publishing services provided by Knowledge

(c) Meitolo Hulu et al. This article is distributed under the terms of the Creative Commons

Attribution License, which permits unrestricted use and redistribution provided that the original author and source are credited.

Selection and Peer-review under the responsibility of the ICE-BEES 2018 Conference Committee.

\section{Abstract}

Tourism activities have a negative and positive impact on the community. Increasing local people's income is one of the positive impacts of tourism activities. This study aims to determine the form of local community participation, economic sustainability of the community who contribute to the development of sustainable tourism in the coastal tourist area of Parangtritis village. Collaboration between community groups that are in direct contact with or not in direct contact with tourism activities remain well established and gain economic benefits from tourism activities in the tourist area of Parangtritis. This research was conducted to both community groups with interview and direct observation techniques. The results of this study indicate that tourism activities in the tourist area Parangtritis provide economic benefits for local communities. Communities in the area of parangtritis have diversified livelihoods, so as to survive in certain situations. For example in fish season, rainy season, dry season and holiday season. Tourists who visit the tourist area of Parangtritis in addition to tourism activities, can also buy crops from local communities that are sold around the tourist area Parangtritis. So that local people get economic benefits related to sustainable tourism activities.

Keywords: Sustainable Tourism, Collaborative, Economic Sustainability.

\section{Preliminary}

Yogyakarta Special Region is one of the leading tourist destinations in Indonesia with the level of tourist arrivals that increase from year to year[1]. Tourism potential in the Special Region of Yogyakarta is a tourist attraction of local and foreign tourists, whether in the form of cultural tourism, nature tourism, and special interest tours. The diversity of tourism in Yogyakarta Special Region becomes an option for tourists to spend their spare time visiting in Yogyakarta Special Region.

Tourism has a positive impact on local communities through increased employment G OPEN ACCESS opportunities, attention to nature conservation, and social and cultural interactions 
between local people and tourists[2]. However, good management of stakeholders is required. Character of good governance one of which is the participation of each stakeholder in making decisions for the common good [3, 4], and becomes key in sustainable tourism development[5]. To increase the involvement of local communities, managers need to give local people the opportunity to invest in tourism activities $[6,7]$.

Local culture becomes capital in the development of tourism that can attract tourist visits while providing business opportunities, jobs for local communities[8]. Understanding for local communities related to negative and positive impacts of economic, social, cultural, and environmental aspects related to tourism development are very important[9]. Since the sustainability of tourism destinations does not escape the involvement of local communities in managing resources and the role of government in making tourism development policy is very important in the sustainability of a region[10].

The involvement of local communities in the coastal tourism area of Parangtritis village is evident from the formation of tourism conscious groups in each tourist attraction. Tourism awareness group (POKDARWIS) consists of local people who daily make a living and live in the vicinity of tourist areas. However, most community groups living far from tourist destinations earn a living by farming, civil servants, entrepreneurs. Collaboration between community groups that are in direct contact or not directly related to tourism activities is needed. This study examines how a form of local community participation in tourism development for the economic sustainability of local communities in the coastal tourist area of Parangtritis village.

\section{Literature Review}

The tourist destination is a location in which it consists of various types of activities, cultures, diverse charms as well as the availability of supporting infrastructure[11, 12]. Community support, environments around destinations are critical to the success of tourist destinations $[13,14]$. The development of community groups through social interaction and empowerment provides long-term impacts for the community itself. Community groups try to do their best for the benefit of their group, so that if any community group is involved in the planning process, it can have long-term impacts on tourism development[15].

The involvement of local communities in the planning process is very effective in increasing public awareness of tourism activities[16, 17], as well as involvement in 
decision-making processes[18]. Local people who deal directly with the tourism industry have a high degree of participation in tourism than people who are not in direct contact with the tourism industry[19]. Because community involvement in tourism development has a direct impact on perceived benefits[20].

The existence of the tourism industry can lead to inequality in local communities, both economically and related to declining environmental conditions[21]. So local governments play a role in the arrangement of tourist areas, promotion, infrastructure development, so that local people can take advantage of business opportunities, work in tourist destinations[13]. Tourism development is tailored to the conditions of local communities as well as integration with other sectors[14]. Collaborative Governance is the involvement of stakeholders in making decisions collectively, making policies, managing programs or assets available for public purposes[22].

Community involvement in tourism activities needs to be enhanced through collaboration between local decision makers and tourism managers[13, 23, 24]. Collaboration between community groups is essential for maintaining social interaction[25]. Although local people have limitations in planning tourism[9]. But to achieve sustainable tourism development can not be separated from the full support of local communities[26] (Gursoy and Rutherford, 2004).

\section{Location and Research Methods}

This research was conducted in Parangtritis Village from May to July 2018. Data collection was done by in-depth interviews to key informants purposively with snowball technique, direct field observation, documentation, and audiovisual[27]. Informants are determined based on the mastery of information and consists of each community group in Parangtritis Village, which is a group of people who touch directly or indirectly related to tourism activities.

Data analysis techniques in this research through several stages of collecting data from various techniques (observation, interview, document, and audiovisual), study all the data collected, provide data codes by theme, and interpret the meaning of the theme [27]). After the analysis, interpretation of data to answer the problems in accordance with the purpose of research. Facts on the ground are constructed without reducing their authenticity, described in full on the form of community participation for economic sustainability. 


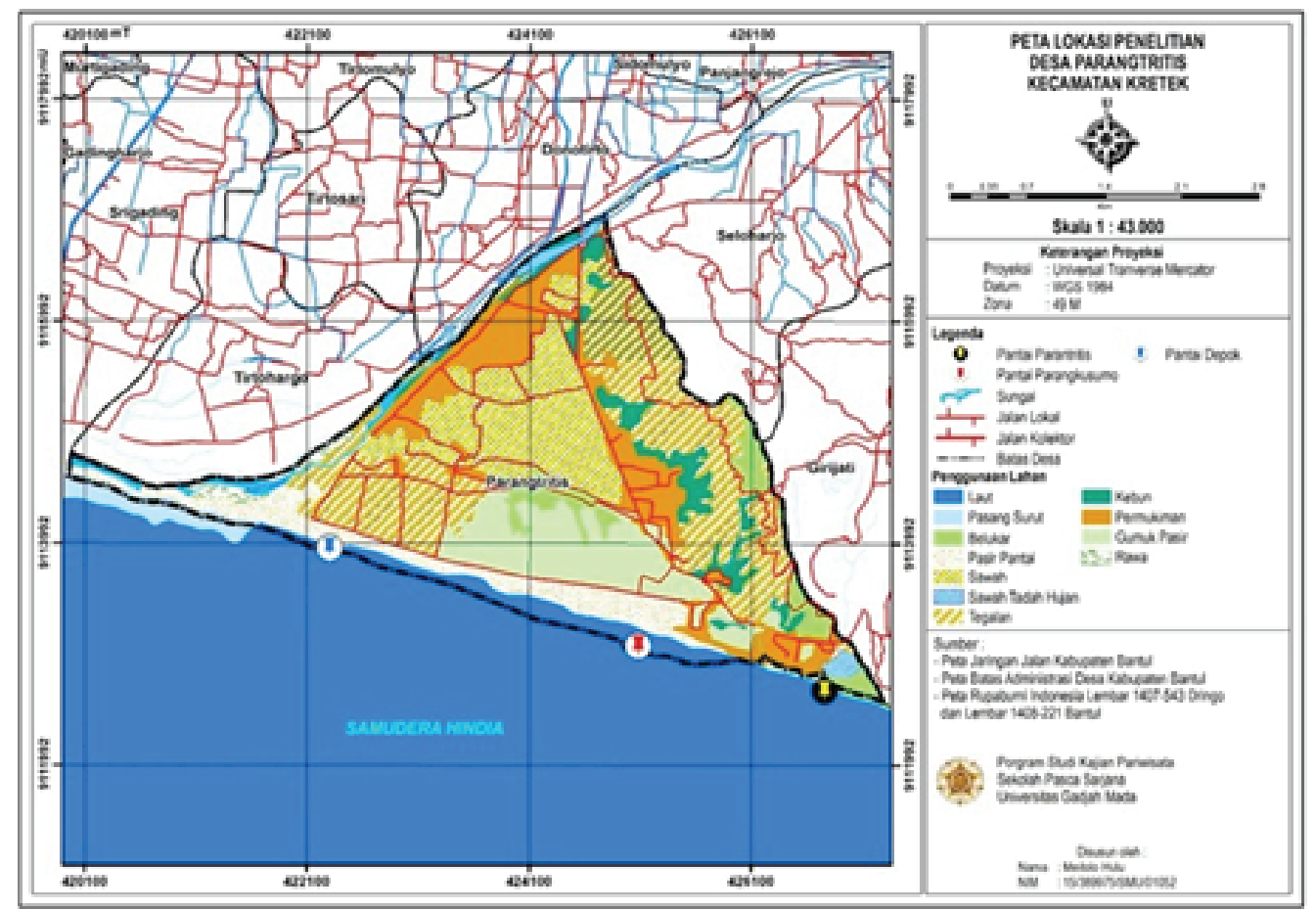

Figure 1: Map of Parangtritis Village.

\section{Discussion}

Community groups who are in direct contact and who are not in direct contact with tourism activities, jointly participate in the development of natural tourist areas in the village of Parangtritis. Collaboration between groups in preserving the environment, culture, social and economic use for the common good. Local people are entitled to be involved in the management of tourism activities. Community involvement is seen from the opportunity to join in tourism services group. Local people in the village of Parangtritis uphold the values of tradition and local wisdom as well as a tourist attraction. One of the local traditions that is done every year is the Merti Dusun ceremony. Merti Dusun is a ceremony performed for generations as a gratitude for salvation and harvest results and at the same time ask for safety to the southern coastal ruler, Nyi Roro Kidul, (interview with local community leaders).

Activities of Merti Dusun involves the whole community including tourist services business groups. This activity as a form of cooperation and community participation towards the preservation of local culture. In addition, the activities of Merti Dusun also attract the attention of visitors by capturing in the form of photos, videos and participate during the ceremony took place. 


\subsection{Community groups in direct contact with tourism activities}

People living close to the coast are almost entirely involved in tourism activities. Many groups are formed according to the type of activities performed. As; parking group, ATV (all terrein vehicle) group, Shops, photography group, Horse group, and Jeep group. Each of these groups benefits economically in terms of tourism activities. One of the shops owners said:

"Here we are all waiting for guests, so if there are no guests quiet and not get the money"

Waiting for the intended guest is the visitors who travel by using the tourism services provided by community groups. The forms of community participation through involvement in tourist services business groups. However, environmental conditions become unnoticed. Decrease in social interaction between local people due to busyness in managing tourism activities.

\subsection{Groups that are not directly in contact with tourism activities}

People living far from coastal areas are mostly farmers, government employees, private employees. The community sells crops around along the way to the beach, and even around tourist destinations. One of the onion farmers in the coastal area of Depok said:

"If a lot of people who pass is usually a lot of buy with a decent price rather than purchased by middlemen"

People who pass the road to the tourist area are tourists from within the city of Yogyakarta and from outside the city of Yogyakarta. Communities are less involved in tourism activities, due to the lack of public knowledge about tourism [28]. Because if the agricultural activities of society can be the object of attraction for tourists, then the benefits obtained more. Naidoo and Sharpley say that agro tourism has the opportunity to be developed as a main tourist attraction [29]. To realize the equity of economic growth not only focuses on coastal areas, but also on agricultural areas that also spread the tourists to gain new experiences while in the tourist area Parangtritis. 


\section{Conclusion}

Most societies have diverse professions. In addition as fishermen are also farmed and incorporated in tourism services business groups. Diversification of local community profession to support the economic sustainability of the community in coastal tourism area Parangtritis. The form of local community participation in tourism development is still not maximal because the utilization of vacant land in tourist area is not in accordance with its designation. The activities of tourist services such as Jeep which route in sand and beach, sand boarding, ATV (All Terrein Vehicle) in coastal area, in addition to lowering the quality of the environment also reduces the comfort of visitors and also increase the worries of visitors in the coastal area.To maintain the economic sustainability of local communities in relation to tourism activities, local people prioritize cultural sustainability, social sustainability, environmental sustainability and become an asset that ultimately can achieve economic sustainability of local communities.

\section{Limitations}

The study only examines the form of local community participation in tourism activities. Future research is expected to examine the form more detail of community participation towards environmental, cultural and social sustainability.

\section{References}

[1] Statistik Kepariwisataan DIY. 2016

[2] Gupta, S.K. and Bhatt, V.P., 2009. Community-based tourism development: A casestudy of eco village Sari in Kedarnath sanctuary region. International Journal of Hospitality and Tourism Systems, 2(1), p.135.

[3] Hall, C. M. (2011). A typology of governance and its implications for tourism policy analysis. Journal of Sustainable Tourism, 19(4-5), 437-457.

[4] Rasoolimanesh, S. M., Ringle, C. M., Jaafar, M., \& Ramayah, T. (2017). Urban vs. rural destinations: Residents' perceptions, community participation and support for tourism development. Tourism Management, 60, 147-158.

[5] Bramwell, B., \& Lane, B. (2011). Critical research on the governance of tourism and sustainability. Journal of Sustainable Tourism, 19(4-5), 411-421. 
[6] Olya, H. G., \& Gavilyan, Y. (2017). Configurational models to predict residents' support for tourism development. Journal of Travel Research, 56(7), 893-912.

[7] Tosun, C. (2006). Expected nature of community participation in tourism development. Tourism management, 27(3), 493-504.

[8] Ahebwa, W. M., Aporu, J. P., \& Nyakaana, J. B. (2016). Bridging community livelihoods and cultural conservation through tourism: Case study of Kabaka heritage trail in Uganda. Tourism and Hospitality Research, 16(2), 103-115.

[9] McGehee, N. G., \& Andereck, K. L. (2004). Factors predicting rural residents's support of tourism. Journal of travel research, 43(2), 131-140.

[10] Baiquni, M., 2007. Strategi penghidupan di masa krisis: belajar dari desa. IdeAs Media.

[11] Buhalis, D. (2000). Marketing the competitive destination of the future. Tourism management, 21(1), 97-116.

[12] Mathew, P. V., \& Sreejesh, S. (2017). Impact of responsible tourism on destination sustainability and quality of life of community in tourism destinations. Journal of Hospitality and Tourism Management, 31, 83-89.

[13] Wilson, S., Fesenmaier, D. R., Fesenmaier, J., \& Van Es, J. C. (2001). Factors for success in rural tourism development. Journal of Travel research, 40(2), 132-138.

[14] Moscardo, G., Konovalov, E., Murphy, L., McGehee, N. G., \& Schurmann, A. (2017). Linking tourism to social capital in destination communities. Journal of Destination Marketing \& Management, 6(4), 286-295.

[15] Hwang, D., Stewart, W. P., \& Ko, D. W. (2012). Community behavior and sustainable rural tourism development. Journal of Travel research, 51(3), 328-341.

[16] Bello, F. G., Lovelock, B., \& Carr, N. (2016). Enhancing community participation in tourism planning associated with protected areas in developing countries: Lessons from Malawi. Tourism and Hospitality Research, 1467358416647763.

[17] Gursoy, D., Chi, C. G., \& Dyer, P. (2010). Locals' attitudes toward mass and alternative tourism: The case of Sunshine Coast, Australia. Journal of Travel Research, 49(3), 381394.

[18] Aas, C., Ladkin, A., \& Fletcher, J. (2005). Stakeholder collaboration and heritage management. Annals of tourism research, 32(1), 28-48.

[19] Kibicho, W. (2004). Community tourism: A lesson from Kenya's coastal region. Journal of Vocation Marketing, 10(1), 33-42.

[20] Lee, T. H. (2013). Influence analysis of community resident support for sustainable tourism development. Tourism management, 34, 37-46. 
[21] Xue, L., \& Kerstetter, D. (2017). Discourse and power relations in community tourism. Journal of Travel Research, 0047287517714908.

[22] Ansell, C. and Gash, A., 2008. Collaborative governance in theory and practice. Journal of public administration research and theory, 18(4), pp.543-571.

[23] Del Chiappa, G., Atzeni, M., \& Ghasemi, V. (2016). Community-based collaborative tourism planning in islands: A cluster analysis in the context of Costa Smeralda. Journal of Destination Marketing \& Management.

[24] Su, L., Huang, S., \& Huang, J. (2016). Effects of destination social responsibility and tourism impacts on residents' support for tourism and perceived quality of life. Journal of Hospitality \& Tourism Research, 1096348016671395.

[25] Hwang, D., Chi, S. H., \& Lee, B. (2016). Collective action that influences tourism: Social structural approach to community involvement. Journal of Hospitality $\&$ Tourism Research, 40(4), 497-515.

[26] Gursoy, D., \& Rutherford, D. G. (2004). Host attitudes toward tourism: An improved structural model. Annals of tourism Research, 31(3), 495-516.

[27] Creswell, J., 2016. Research Design Pendekatan Metode Kualitatif, Kuantitatif, dan Campuran Edisi 4 (terj). Pustaka Pelajar. Yogyakarta.

[28] Wise, N., Mulec, I., \& Armenski, T. (2017). Towards a new local tourism economy: Understanding sense of community, social impacts and potential enterprise opportunities in Podgrađe Bač, Vojvodina, Serbia. Local Economy, 32(7), 656-677.

[29] Naidoo, P., \& Sharpley, R. (2016). Local perceptions of the relative contributions of enclave tourism and agritourism to community well-being: The case of Mauritius. Journal of Destination Marketing \& Management, 5(1), 16-25. 